\title{
Doświadczenia badanych pacjentek oddziału położniczo - neonatologicznego dotyczące opieki pielęgniarskiej w okresie hospitalizacji w zależności od wybranych zmiennych socjodemograficznych z wykorzystaniem polskiej wersji skali NEWCASTLE
}

The examined patients needs/ experience of the obstetricneonatological unit with reference to nursing care during the hospital stay , depending on the selected sociodemographic variables using the polish version of the scale of NEWCASTLE

DOROTA KOCHMAN ${ }^{1}$, PAULINA WOJASIŃSKA ${ }^{2}$

1Państwowa Wyższa Szkoła Zawodowa we Włocławku, Instytut Nauk o Zdrowiu ORCID ID: https://orcid.org/0000-0002-3221-712X

2 Oddział dziecięcy, pododdział neonatologiczny SPZOZ Radziejów

DOI: http://dx.doi.org/10.21784/IwP.2019.002

ISSN: 2451-1846

Streszczenie:

Wstęp. Poziom zadowolenia pacjentów z opieki jest jednym z najważniejszych czynników służących całościowej ocenie opieki podczas pobytu w szpitalu.

Cel. Celem pracy jest analiza doświadczeń badanych pacjentek oddziału położniczo - neonatologicznego dotyczących opieki pielęgniarskiej w okresie hospitalizacji. 
Materiał i metody. W pracy wykorzystano metodę sondażu diagnostycznego oraz metodę szacowania, jako technikę - ankietowanie i skalę szacunkową. Narzędziem uczyniono polską wersję skali zadowolenia z opieki NEWCASTLE (część pierwsza). W przeprowadzonych badaniach udział wzięło 50 osób.

Wyniki. Doświadczenia badanych dotyczące opieki pielęgniarskiej w okresie hospitalizacji nie różnią się istotnie w zależności od wybranych zmiennych socjodemograficznych (wiek, wykształcenie, miejsce zamieszkania), czasu hospitalizacji i korzystania ze wsparcia ze strony pielęgniarek.

Wnioski. Oddział noworodkowy jest tym miejscem, w którym szczególną uwagę należy zwrócić na doświadczenia i satysfakcję badanych z opieki pielęgniarskiej, ponieważ opieka sprawowana w oddziale nad matką i noworodkiem może pośrednio wpłynąć na zakres opieki realizowanej przez rodziców/opiekunów w domu.

Słowa kluczowe: jakość opieki, skala Newcastle, doświadczenia pacjentek

\begin{abstract}
:
Introduction. The level of patients ' satisfaction with medical care is one of the most important factors that serves a comprehensive assessment of care during the hospital stay.
\end{abstract}

Aim. The aim of the study is to analyse the experience of the patients of the obstetric-neonatological unit.

Material and methods. The work uses the method of diagnostic survey and the method of estimation as a technique - questionnaire and estimation scale. The polish version of the NEWCASTLE care satisfaction scale was selected as a tool (first part). A total of 50 participants took part in the research.

Results. The respondents 'experience relating to nursing care during the hospital stay did not vary significantly in realation to the selected sociodemografic variables (age, education, place of residence), time of hospitalization and the use of support from the nurses.

Conclusions. The neonatology unit is the place where special attention should be paid to the experience of patients and satisfaction with nursing care, because medical care for the mother and newborn may indirectly affect the care performed by parents/guardians at home. 
Key words: quality of medical care, NEWCASTLE care satisfaction scale, the experience of patients

\section{Wstęp}

Fakt potrzeby badania poziomu zadowolenia $\mathrm{z}$ opieki pielęgniarskiej/położniczej nie budzi wątpliwości. Wyniki przeprowadzanych badań jasno pokazują, iż poziom zadowolenia pacjentów z opieki jest jednym $\mathrm{z}$ najważniejszych czynników służących całościowej ocenie opieki podczas pobytu w szpitalu [1]. Jakość opieki sprawowanej przez personel pielęgniarski/położniczy $\mathrm{w}$ doświadczeniach pacjenta/pacjentki nazywany jest często miernikiem ewaluacji nie tylko opieki pielęgniarskiej/położniczej, ale i całościowej opieki w danej jednostce opieki zdrowotnej. Należy pamiętać, że pacjent, który jest świadczeniobiorcą w danej jednostce opieki zdrowotnej ma prawo wymagać jak najlepszej jakościowo opieki. Zapewnienie odpowiednio wysokiej jakości sprawowanych usług medycznych wymaga nie tylko zastosowania nowoczesnych technik, ale również pełnego zaangażowania nie tylko ze strony zarządzających daną jednostka opieki zdrowotnej, ale i wszystkich jej pracowników. Wynika to bowiem z interdyscyplinarnego charakteru sprawowania opieki zdrowotnej. Niezwykle istotnym ogniwem opieki są pielęgniarki i położne, które wykonują coraz szerszy zakres świadczeń $[2,3,4]$.

Obecnie $\mathrm{w}$ omawianym zakresie opieramy się o Standardy opieki nad noworodkiem i położnicą w okresie okołoporodowym regulowane przez Rozporządzenie Ministra Zdrowia z dnia 16 sierpnia 2018r. w sprawie standardu organizacyjnego opieki okołoporodowej [5].

Celem pracy jest analiza doświadczeń badanych pacjentek oddziału położniczo - neonatologicznego dotyczących opieki pielęgniarskiej w okresie hospitalizacji. 


\section{Materiał i metody}

W pracy wykorzystano metodę sondażu diagnostycznego oraz metodę szacowania, jako technikę - ankietowanie i skalę szacunkową. Narzędziem uczyniono polską wersję skali zadowolenia z opieki NEWCASTLE (część pierwsza). Skala ta służy do oceny doświadczeń związanych z opieką pielęgniarskiej oraz satysfakcji pacjenta $\mathrm{z}$ tej opieki.

Wyniki przeprowadzanych badań zostały poddane analizie statystycznej. Występowanie współzależności między zmiennymi, obliczone zostało za pomocą współczynnika korelacji R Spearmana. Współczynnik ten, służy do opisu sił korelacji występujących pomiędzy dwoma cechami, gdy mają one charakter jakościowy i istnieje możliwość uporządkowania obserwacji empirycznych w określonej kolejności lub w sytuacji gdy mamy do czynienia z cechami ilościowymi. Zastosowano również nieparametryczny test U Manna - Whitneya w celu oceny różnic jednej cechy pomiędzy dwoma grupa. W pracy wykorzystany został także test rang Kruskala - Wallisa, który stosowany jest do porównywania wielu niezależnych grup. Jako hipotezę zerową przyjęto, brak różnic w badanych grupach. Jako poziom istotności statystycznej przyjęto $\mathrm{p}>0,05$.

W przeprowadzonych badaniach udział wzięło 50 osób. Średnia wieku badanych wyniosła 28 lat. Najmłodsza z respondentek miała 18 lat, najstarsza 41. Najliczniejszą grupę badanych stanowiły osoby pomiędzy 26 a 30 rokiem życia, najmniej liczną osoby po 30 roku życia.

Respondenci podzieleni zostali na grupy ze względu na wykształcenie. Wykształcenie podstawowe posiadała jedna osoba (2\% badanych), wykształcenie zawodowe dotyczyło 10 osób (20\%), średnim legitymowały się 24 pacjentki (48\%) a wyższym 15 (30\%) spośród ankietowanych. Najliczniejszą grupę stanowiły pacjentki z wykształceniem średnim, a najmniej liczną $\mathrm{z}$ podstawowym. 
Do celów dalszej analizy osoba ta została zakwalifikowana do grupy z wykształceniem zawodowym.

Średnia ilość nocy, które respondentki spędziły w oddziale wyniosła 4. Najdłuższy pobyt trwał 8 nocy, najkrótszy 2. Odchylenie standardowe wynosiło $36,4 \%$ co świadczy o znacznym zróżnicowaniu ilości dni spędzonych $\mathrm{w}$ oddziale przez pacjentki. Połowa badanych (25 osób, 50\%) w oddziale spędziły do 3 nocy. Pobyt pozostałych był dłuższy.

Ponad połowa badanych (26 osób,52\%) uważała, że nie miała wyznaczonej konkretnej pielęgniarki sprawującej nad nimi opiekę. Z kolei 19 kobiet (38\%) nie było pewnych tego faktu, natomiast 5 osób (10\%) uważało, że opieka nad nimi sprawowana była przez konkretnie wyznaczoną pielęgniarkę.

Zdecydowaną większość respondentek stanowiły kobiety zamężne - 36 osób (76\%). W gronie badanych jedna (2\%) deklarowała stan cywilny jako rozwiedziona. Pozostała grupa, czyli $22 \%$ (11 osób) to panny.

Większość kobiet (35 osób,70\%) biorących udział w badaniu zamieszkiwało na wsi, a 15 osób (30\%) w mieście.

\section{Wyniki}

Pytania zawarte w kwestionariuszu Skali zadowolenia z opieki pielęgniarskiej - NEWCASTLE dotyczą opieki pielęgniarskiej świadczonej przez personel oraz poglądów badanych na tę opiekę. Analizowany zestaw pytań dotyczy doświadczeń respondentów związanych z opieką pielęgniarską.

Największa liczba ankietowanych całkowicie zgadzała się $\mathrm{z}$ twierdzeniem, że z pielęgniarkami pracującymi w oddziale można było żartować. Ocenę tę wybrało 21 osób (42\%). Bardzo zgodziło się z nim 14 osób (28\%), a trochę zgodziło się kolejne 11 pacjentek (22\%). Tylko jedna spośród badanych kobiet całkowicie się z nim nie zgodziła, i kolejna jedna trochę się nie zgodziła, a 2 (4\%) nie miały zdania na temat ww. twierdzenia. 
Większość ankietowanych (74\%, 37 osób) całkowicie nie zgadzało się $\mathrm{z}$ twierdzeniem, że pielęgniarki faworyzowały niektórych pacjentów. Kolejne 7 osób (14\%) bardzo się nie zgodziło z tym stwierdzeniem, a jedna tylko trochę się nie zgodziła. Następne 5 osób (10\%) nie miało zdania w tej kwestii. Szczególną uwagę należy zwrócić na fakt, że żadna $\mathrm{z}$ pacjentek nie wybrała odpowiedzi potwierdzającej ww. twierdzenie.

Zdecydowana większość (54\% - 27 osób) nie zgodziła się z twierdzeniem, że pielęgniarki nie udzielały wystarczających informacji całkowicie, 11 (22\%) bardzo a 2(4\%) tylko trochę. Odpowiedzi potwierdzające ww. tezę (trochę się zgadzam, bardzo się zgadzam, całkowicie się zgadzam) wybrane zostały łącznie tylko przez 5 pacjentek (10\%). 5 osób nie miało zdania w tej kwestii.

Większość respondentek (33 osoby - 66\%) całkowicie nie zgadzało się $\mathrm{z}$ twierdzeniem, że pielęgniarki $\mathrm{w}$ pracy były zbyt swobodne oraz nie wkładały dużo wysiłku w działania zawodowe. Nie zgadzało się zdecydowanie $\mathrm{z}$ ww. opinią 10 osób (20\%). Tylko 3 pacjentki nie miały zdania na ten temat. Ważny jest fakt, że z twierdzeniem tym zgodziły się tylko $4(8 \%)$ spośród ankietowanych.

Większość (52\% - 26 osób) badanych całkowicie nie zgodziło się z twierdzeniem, że przybycie pielęgniarek na wezwanie odbywało się zbyt wolno. Duża grupa (18\% - 9 osób) badanych bardzo lub trochę nie zgodziło się $\mathrm{z}$ twierdzeniem, że przybycie pielęgniarek na wezwanie odbywało się zbyt wolno. Zdania na ten temat nie miało 3 osoby (6\%). Zaś łącznie 12 osób (24\%) całkowicie, bardzo lub trochę zgodziło się z tym twierdzeniem.

Zdecydowana większość ankietowanych (30 osób - 60\%) całkowicie zgodziło się z twierdzeniem, że informacje udzielane były przez pielęgniarki w czasie, w którym tego potrzebowali. Z powyższą opinią trochę się zgadza 1 osoba (2\%). Tylko 3 (6\%) spośród badanych kobiet uznało, że pielęgniarki nie udzielały im informacji w czasie, w którym tego potrzebowały. Tylko 5 pacjentek nie miało zdania na ten temat. 
Najwięcej badanych całkowicie nie zgodziło się z twierdzeniem, że pielęgniarki lekceważyły ich cierpienie. Odpowiedz ta została wybrana przez 38 osób (76\%). Odpowiedz bardzo się nie zgadzam wybrana została przez 5 pacjentek (10\%). Opinia „trochę się nie zgadzam" wybrana została przez tylko 1 pacjentkę (2\%), a 2 kobiety (4\%) nie miały zdania na temat ww. twierdzenia. Odpowiedź „bardzo się zgadzam” i „całkowicie się zgadzam” wybrane zostały odpowiednio przez 2 osoby (4\%).

Zdecydowana większość badanych (36 osób,72\%) całkowicie nie zgodziło się z twierdzeniem, że pielęgniarki gasiły światło zbyt późno w nocy. Bardzo i trochę nie zgadzało się z tą opinią łącznie 9 osób(18\%). Przeciwnego zdania była jedna (2\%) spośród ankietowanych pacjentek, a 4 osoby nie miały w tej kwestii zdania.

Większość ankietowanych (27 osób - 54\%) całkowicie nie zgodziło się z twierdzeniem, że pielęgniarki kazały im wykonywać określone czynności, zanim były do nich przygotowane. Bardzo nie zgodziło się z nim 8 osób (16\%).Tylko 3 (6\%)respondentki nie miały zdania na temat ww. twierdzenia i tyleż samo trochę się zgodziło z tym twierdzeniem. Należy zauważyć, że aż 7 kobiet (14\%) całkowicie się z nim zgodziło a jedna osoba bardzo się zgodziła.

Prawie połowa badanych (24 osoby - 48\%) całkowicie zgodziła się z twierdzeniem, że pielęgniarki niezależnie jak bardzo były zajęte znajdowały dla nich czas. Zauważyć trzeba również, że dodatkowo 18 (36\%) pacjentek bardzo się $\mathrm{z}$ nim zgodziło oraz 3 osoby (6\%) trochę się z nim zgodziły. Zdania na ten temat nie miała jedna $z$ ankietowanych (2\%). Ważny jest również fakt, że z twierdzeniem tym zgodziły się jedynie 4 (8\%) spośród ankietowanych.

Ponad jedna trzecia badanych (18 osób -36\%) bardzo zgodziła się $\mathrm{z}$ twierdzeniem, że widziały $\mathrm{w}$ pielęgniarkach swoich przyjaciół. Całkowicie zgodziło się z nim 16 osób(32\%). Jedynie 8 pacjentek (16\%) wybrało odpowiedź trochę się zgadzam, a 4 (8\%) nie miały 
zdania na temat ww. twierdzenia. Należy zauważyć również, że z twierdzeniem tym łącznie nie zgodziły się 4 badane.

Prawie połowa badanych (22 osoby - 44\%) całkowicie zgodziła się $\mathrm{z}$ twierdzeniem, że pielęgniarki pocieszały przygnębionych pacjentów, bardzo i trochę pocieszały odpowiednio 13 osób - 26\% i 6 osób - 12\%. Należy zwrócić uwagę na fakt, że żadna z badanych kobiet nie określiła swojego zdania jako trochę się zgadzam, a całkowicie/bardzo się zgadzam w czasie badania wybrane łącznie przez 2 osoby (4\%). Nie miało zdania na ten temat 7 osób (14\%).

Zdecydowana większość ankietowanych (31 osób -62\%) całkowicie zgodziło się z twierdzeniem, że pielęgniarki regularnie sprawdzały czy u nich wszystko w porządku. Zauważyć należy również, że z twierdzeniem tym bardzo zgodziły się 4 pacjentki (8\%) a trochę się z nim zgodziły 2 spośród ankietowanych (4\%). Ważny jest również fakt, że jedynie 11 kobiet (22\%) nie zgodziło się z nim. Nie miało zdania na ten temat 2 osoby (4\%).

Zdecydowana większość badanych (35osób -70\%) całkowicie nie zgodziła się z twierdzeniem, że pielęgniarki pracujące w oddziale nie ze wszystkim dawały sobie radę. Aż 12 pacjentek (24\%) bardzo się z nim nie zgodziło, a jedna osoba (2\%) trochę się z nim nie zgodziła (podobnie jak $\mathrm{z}$ twierdzeniem trochę się zgadzam i bardzo się zgadzam).

Większość badanych (40 osób - 80\%) całkowicie nie zgodziło się $\mathrm{z}$ twierdzeniem, że pielęgniarki nie wykazywały nimi zainteresowania. Zauważyć trzeba również, że bardzo nie zgodziło się $\mathrm{z}$ tą opinią 7 pacjentek (14\%). Jedna osoba (2\%) nie miała zdania na temat ww. twierdzenia, a potwierdziły je 2 (4\%) spośród ankietowanych

Zdecydowana większość pacjentek (30 osób - 60\%) całkowicie zgodziła się ztwierdzeniem, że pielęgniarki tłumaczyły im ich dolegliwości. Bardzo lub trochę zgodziło się z nim 13 (26\%) spośród ankietowanych. Zauważyć trzeba również, że jedna z kobiet nie miała 
zdania na temat ww. twierdzenia a $12 \%$ badanych nie zgodziło się $\mathrm{z}$ nim.

Większość respondentek (28 osób -56\%) całkowicie zgodziło się z twierdzeniem, że pielęgniarki tłumaczyły im przed zabiegiem na czym będzie on polegał. Na uwagę zasługuje również fakt, że aż 12 pacjentek (24\%) bardzo się z nim zgodziło a 4 osoby (8\%) wybrały odpowiedz "trochę się zgadzam". Zauważyć należy również fakt, że 3 pacjentki (6\%) nie miały zdania na temat ww. twierdzenia a 2 spośród ankietowanych (4\%) trochę się z nim nie zgadzało. Jedna osoba $(2 \%)$ całkowicie nie zgadzała się $\mathrm{z}$ ww. twierdzeniem

Zdecydowana większość badanych (31 osób -62\%) całkowicie zgodziło się z twierdzeniem, że pielęgniarki przekazywały następnej zmianie informacje o stanie zdrowia pacjentów, zaś 14 - 28\% łącznie zgodziło się bardzo i trochę. Najrzadziej (po 1 osoba - 2\%) wybrane zostały odpowiedzi „całkowicie się nie zgadzam” oraz „bardzo się nie zgadzam". Trzy osoby nie miały zdania na ten temat.

Ponad jedna trzecia badanych (18 osób -36\%) całkowicie zgodziło się z twierdzeniem, że pielęgniarki wiedziały co robić bez zlecenia lekarskiego. Bardzo się z nim zgodziło 14 osób (28\%), a 2 pacjentki (4\%) trochę się $\mathrm{z}$ nim zgodziły (podobnie jak trochę się nie zgodziło). Jedynie 4 ankietowane (8\%) nie miały zdania na temat ww. twierdzenia. Należy zauważyć, że 12(24\%) respondentek uważało, że pielęgniarki nie wiedziały co powinny zrobić bez konkretnego polecenia lekarza.

Zdecydowana większość ankietowanych (37 osób - 74\%) całkowicie nie zgodziło się z twierdzeniem, że pielęgniarki zapominały o co pacjent je prosił, a dodatkowo 5 pacjentek (10\%) odpowiedz bardzo się z nim nie zgodziło. Kolejne 2 (4\%) spośród badanych trochę się $\mathrm{z}$ nim nie zgadzały. Ważny jest również fakt, że tylko jedna pacjentka (2\%) nie miała zdania na temat ww. twierdzenia, a tylko $10 \%$ respondentek się z nim zgodziło.

Zdecydowana większość (31 osób - 62\%) całkowicie zgodziło się z twierdzeniem, że pielęgniarki dbały o ich prywatność. Odpowiedz 
bardzo się zgadzam wybrana została przez 10 kobiet (20\%) a tylko 3 respondentki (6 \%) uznały, że pielęgniarki nie dbały o ich prywatność.

Mniej niż jedna trzecia badanych (12 osób - 24\%) całkowicie zgodziło się z twierdzeniem, że pielęgniarki znajdowały czas na rozmowę z pacjentem. Dodatkowo zauważyć trzeba, że 10 kobiet (20\%) bardzo się z nim zgodziło oraz trochę się zgodziło. Ważny jest jednak również fakt, że 7 osób (14\%) nie miało zdania na temat ww. twierdzenia, a tylko 6 kobiet ( $12 \%$ ) nie zgodziło się z nim.

Zdecydowana większość (45 osoby - 90\%) całkowicie bardzo i trochę zgodziło się z twierdzeniem, że pielęgniarki i lekarze pracowali dobrze jako zespół. Przeciwnego zdania (odpowiedz całkowicie się nie zgadzam) były jedynie $2(4 \%)$ pacjentki.

Zdecydowana większość badanych (34 osoby -68\%) całkowicie nie zgodziło się z twierdzeniem, że jedna pielęgniarka nie wiedziała, co robi druga. Zauważyć trzeba równie, że 9 osób (18\%) wybrało odpowiedz bardzo i trochę się nie zgadzam, natomiast 3 pacjentki (6\%) nie miały zdania na temat ww. twierdzenia. Ważny jest również fakt, że 4 pacjentki (8\%) trochę, bardzo lub całkowicie się z nim zgodziły.

Większość pacjentek (30 osób - 60\%) całkowicie zgodziło się z twierdzeniem, że pielęgniarki wiedziały co robić, aby było jak najlepiej. Prawie jedna trzecia (13 osób-26\% ) bardzo się z nim zgodziło, a tylko 3 (6\%) spośród ankietowanych kobiet się z nim nie zgodziła.

Zdecydowana większość ankietowanych (44 osób - 88\%) całkowicie lub bardzo zgodziło się ztwierdzeniem, że dzięki pielęgniarkom na oddziale panowała miła atmosfera. Odpowiedzi zaprzeczające tej tezie wybrane łącznie zostały przez tylko 2 osoby (4\%). 
Tabela 1. Średnie wyniki poszczególnych aspektów związanych z doświadczeniami z opieki pielęgniarskiej.

\begin{tabular}{|c|c|c|c|c|c|}
\hline $\mathrm{Nr}$ & treśść & WO* & średnia & SD & $\begin{array}{c}\text { wskaźnik } \\
\%\end{array}$ \\
\hline 1 & \begin{tabular}{|l|l|} 
można było pożartować \\
z pielęgniarkami
\end{tabular} & 6 & 4,96 & 1,228 & 82,7 \\
\hline 2 & \begin{tabular}{|l|} 
pielęgniarki faworyzowały \\
niektórych pacjentów
\end{tabular} & 6 & 5,52 & 0,953 & 92,0 \\
\hline 3 & $\begin{array}{|ll|}\begin{array}{l}\text { pielęgniarki nie udzielały } \\
\text { wystarczających odpowiedzi }\end{array} & \mathrm{mi} \\
\end{array}$ & 6 & 4,90 & 1,644 & 81,7 \\
\hline 4 & \begin{tabular}{|l|l|} 
pielęgniarki nie wysilały się \\
zbytnio \\
i były zbyt swobodne
\end{tabular} & 6 & 5,24 & 1,437 & 87,3 \\
\hline 5 & $\begin{array}{l}\text { przybycie na wezwanie zabierało } \\
\text { dużo czasu }\end{array}$ & 6 & 4,28 & 2,322 & 71,3 \\
\hline 6 & \begin{tabular}{|l|} 
pielęgniarki udzielały informacji \\
w chwili potrzeby
\end{tabular} & 6 & 5,08 & 1,602 & 84,7 \\
\hline 7 & $\begin{array}{l}\text { wydawało mi się, ze pielęgniarki } \\
\text { lekceważą moje cierpienie }\end{array}$ & 6 & 5,30 & 1,594 & 88,3 \\
\hline 8 & $\begin{array}{|ll|}\begin{array}{l}\text { pielęgniarki gasiły światło zbyt } \\
\text { późno w nocy }\end{array} & \\
\end{array}$ & 6 & 5,42 & 1,197 & 90,3 \\
\hline 9 & $\begin{array}{l}\text { pielęgniarki kazały mi wykonywać } \\
\text { czynności bez przygotowania }\end{array}$ & 6 & 4,44 & 2,224 & 74,0 \\
\hline 10 & $\begin{array}{l}\text { pielęgniarki niezależnie jak były } \\
\text { zajęte znajdowały dla mnie czas }\end{array}$ & 6 & 5,04 & 1,470 & 84,0 \\
\hline 11 & $\begin{array}{|lc|}\begin{array}{l}\text { widziałem } \\
\text { swoich przyjaciół }\end{array} & \text { pielęgniarkach } \\
\end{array}$ & 6 & 4,72 & 1,325 & 78,7 \\
\hline 12 & $\begin{array}{l}\begin{array}{l}\text { pielęgniarki pocieszały pacjentów, } \\
\text { którzy byli przygnębieni }\end{array} \\
\end{array}$ & 6 & 4,86 & 1,400 & 81,0 \\
\hline 13 & $\begin{array}{l}\text { pielęgniarki regularnie sprawdzały, } \\
\text { czy u mnie wszystko dobrze }\end{array}$ & 6 & 4,50 & 2,297 & 75,0 \\
\hline 14 & \begin{tabular}{|l}
$\begin{array}{l}\text { pielęgniarki nie ze } \\
\text { dawały sobie radę }\end{array}$ \\
\end{tabular} & 6 & 5,54 & 0,973 & 92,3 \\
\hline 15 & $\begin{array}{l}\text { pielęgniarki nie interesowały się } \\
\text { mną }\end{array}$ & 6 & 5,66 & 0,895 & 94,3 \\
\hline 16 & $\begin{array}{|llll|}\begin{array}{l}\text { pielęgniarki } \\
\text { dolega }\end{array} & \text { thumaczyły } & \text { co } & \mathrm{mi} \\
\end{array}$ & 6 & 02 & 1,672 & 83,7 \\
\hline 17 & $\begin{array}{|lr|}\text { przed zabiegiem } & \text { pielęgniarki } \\
\text { thumaczyły mi na czum on polega }\end{array}$ & 6 & 5,14 & 1,325 & 85,7 \\
\hline 18 & $\begin{array}{|lrr|}\text { pielęgniarki } & \text { przekazywały } \\
\text { następnej } & \text { zmianie } & \text { informacje } \\
\end{array}$ & 6 & 5,28 & 1,294 & 88,0 \\
\hline
\end{tabular}




\begin{tabular}{|c|l|c|c|c|c|}
\hline & dotyczące mojego stanu & & & & \\
\hline 19 & $\begin{array}{l}\text { pielęgniarki wiedziały co robić, nie } \\
\text { czekały na polecenia lekarzy }\end{array}$ & 6 & 4,16 & 2,093 & 69,3 \\
\hline 20 & $\begin{array}{l}\text { zdarzało się, że pielęgniarki } \\
\text { odchodziły i zapominały o co } \\
\text { prosił pacjent }\end{array}$ & 6 & 5,24 & 1,648 & 87,3 \\
\hline 21 & $\begin{array}{l}\text { pielęgniarki dbały o prywatność } \\
\text { pacjentów }\end{array}$ & 6 & 5,12 & 1,599 & 85,3 \\
\hline 22 & $\begin{array}{l}\text { pielęgniarki miały czas by usiąśćc } \\
\text { i porozmawiać ze mną }\end{array}$ & 6 & 3,92 & 1,782 & 65,3 \\
\hline 23 & $\begin{array}{l}\text { lekarz i pielęgniarki pracowali } \\
\text { dobrze jako zespół }\end{array}$ & 6 & 5,32 & 1,406 & 88,7 \\
\hline 24 & $\begin{array}{l}\text { wydawało mi się, że jedna } \\
\text { pielęgniarka jakby nie wiedziała co } \\
\text { robi druga }\end{array}$ & 6 & 5,24 & 1,451 & 87,3 \\
\hline 25 & $\begin{array}{l}\text { pielęgniarki wiedziały co robić aby } \\
\text { było jak najlepiej }\end{array}$ & 6 & 5,20 & 1,457 & 86,7 \\
\hline 26 & $\begin{array}{l}\text { dzięki pielęgniarkom na oddziale } \\
\text { panowała miła atmosfera }\end{array}$ & 6 & 5,28 & 1,325 & 88,0 \\
\hline
\end{tabular}

Źródło: wynik badań własnych

W celu obliczenia ogólnej punktacji dotyczącej doświadczeń z opieki pielęgniarskiej dokonano przekodowania uzyskanych odpowiedzi. Za wartość oczekiwaną przyjęto uzyskanie 6 pkt.

Najwyższy wskaźnik procentowy w stosunku do wartości oczekiwanej otrzymały twierdzenia respondentek:

1. Pielęgniarki nie interesowały się mną (15) - wskaźnik procentowy wyniósł $94,3 \%$. Oznacza to, że $94,3 \%$ ankietowanych nie zgodziło się z ww. twierdzeniem.

2. Pielęgniarki nie ze wszystkim dawały sobie radę (14) - wskaźnik procentowy wyniósł $92.3 \%$. Oznacza to, że 92,3\% pacjentek nie zgodziło się z ww. twierdzeniem.

3. Pielęgniarki faworyzowały niektórych pacjentów (2) - wskaźnik procentowy wyniósł 92,0\%. Oznacza to, że w 92,0\% kobiet nie zgodziło się z ww. twierdzeniem. 
Najniższy wskaźnik procentowy w stosunku do wartości oczekiwanej otrzymały twierdzenia respondentek:

1. Pielęgniarki kazały mi wykonywać czynności bez przygotowania (9) - wskaźnik procentowy wyniósł $74,0 \%$. Oznacza to, że $74.0 \%$ ankietowanych nie zgodziło się z ww. twierdzeniem.

2. Przybycie na wezwanie zabierało dużo czasu (5) - wskaźnik procentowy wyniósł $71,3 \%$. Oznacza to, że $71,3 \%$ badanych nie zgodziło się z ww. twierdzeniem.

3. Pielęgniarki wiedziały co robić, nie czekały na polecenie lekarzy(19) - wskaźnik procentowy wyniósł 69,3\%. Oznacza to, że 69,3\% kobiet zgodziło się z ww. twierdzeniem.

Średnia ocena doświadczeń z opieki pielęgniarskiej w oddziale neonatologicznym wyniosła 83,58pkt. Odchylenie standardowe stanowi 17,28\% wartości średniej, co świadczy o przeciętnym zróżnicowaniu wyników. Ocena minimalna wynosi $44,87 \%$ natomiast maksymalna $100 \%$.

\section{Dyskusja}

Przeanalizowano oceny doświadczeń z opieki pielęgniarskiej w poszczególnych grupach wiekowych respondentek. Najlepsze doświadczenia w tym zakresie uzyskały badane powyżej 30 roku życia - średnia 86,54 pkt. Osoby w wieku 26-30 lat otrzymały średni wynik $85,66 \%$. Najniższy wyniki uzyskały pacjentki w wieku do 25 lat średnia 78,33 pkt. 


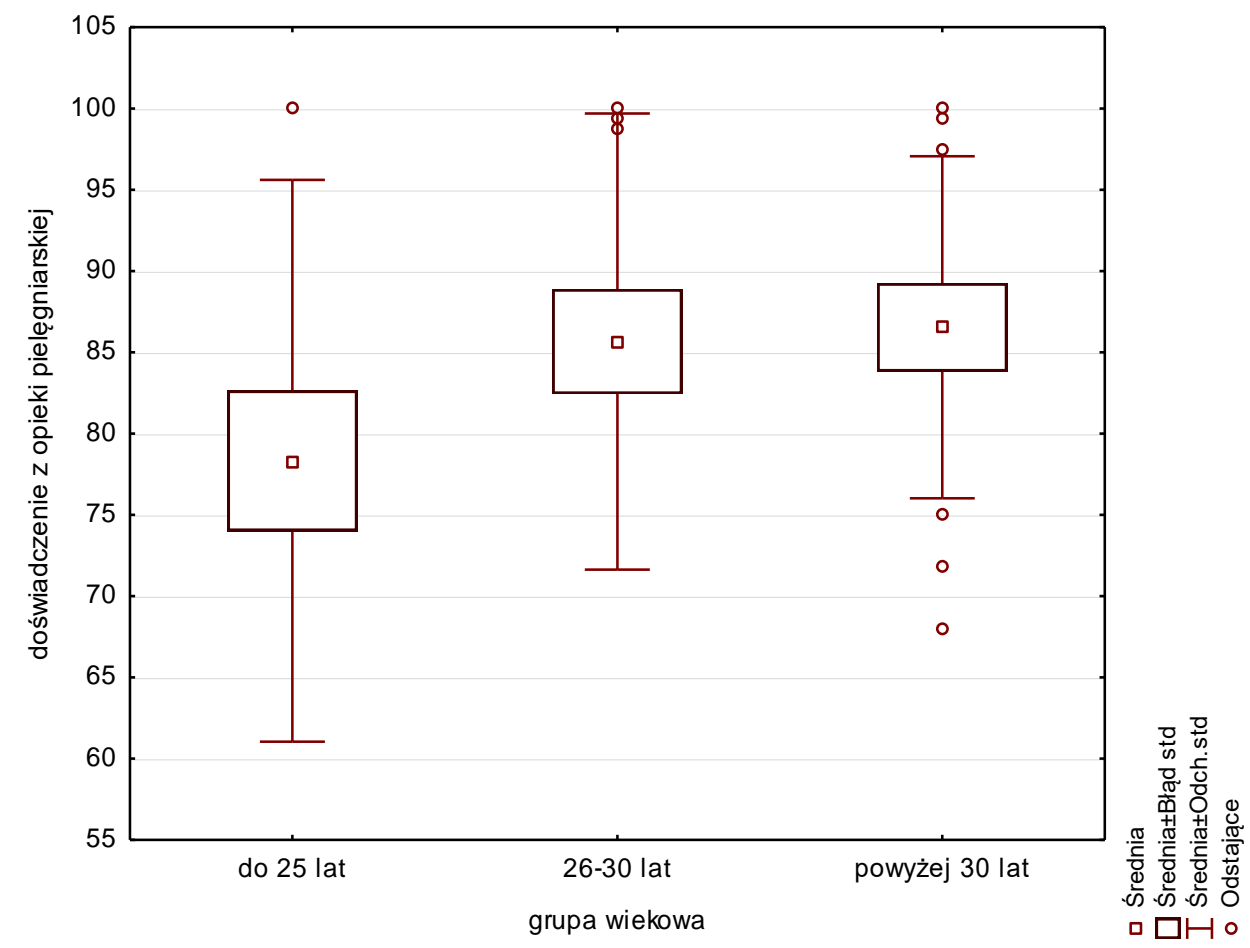

Rycina 1. Rozkład średnich punktacji dotyczących doświadczeń badanych $\mathrm{z}$ opieki pielęgniarskiej w poszczególnych grupach wiekowych.

Źródło: wynik badań własnych

Wiek badanych, nie pozostawał $\mathrm{w}$ istotnej statystycznie korelacji z oceną ich doświadczeń z opieki pielęgniarskiej w oddziale $p=0,207(p>0,05)$.

Przeanalizowano punktację doświadczeń $\mathrm{z}$ opieki pielęgniarskiej w zależności od poziomu wykształcenia badanych. Najlepsze doświadczenia $\mathrm{w}$ tym zakresie uzyskały respondentki z wykształceniem wyższym - średnia 86,45 pkt. Najniższe z kolei osoby z wykształceniem zawodowym - średnia 80,13 pkt., osoby z wykształceniem średnim uzyskały średnią punktacji 83,36. 


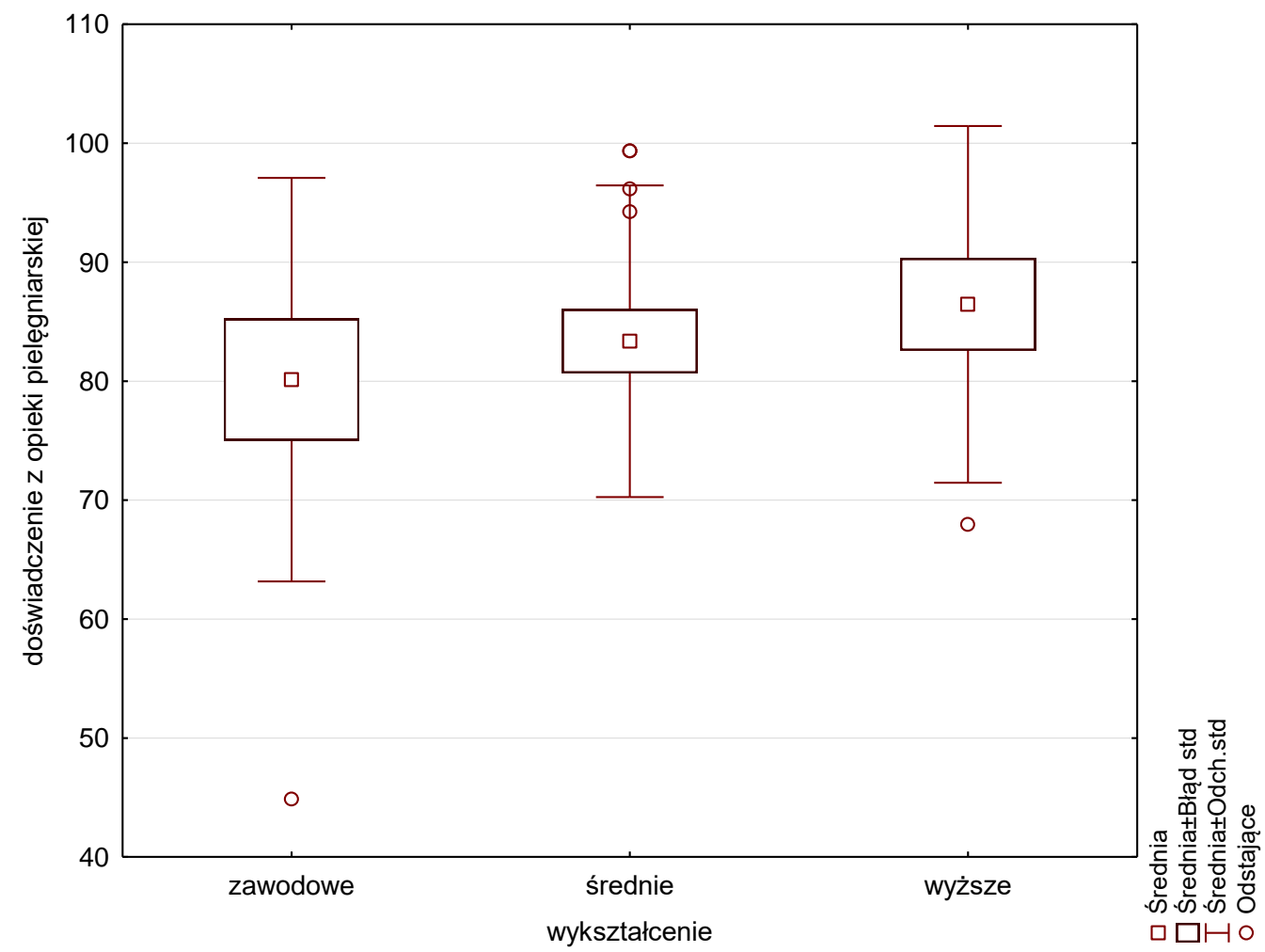

Rycina 2. Rozkład średnich punktacji doświadczeń badanych z opieki pielęgniarskiej w zależności od wykształcenia.

Źródło: wynik badań własnych

Wykształcenie badanych nie pozostawało $w$ istotnej statystycznie korelacji z oceną doświadczeń z opieki pielęgniarskiej $\mathrm{p}=0,273(\mathrm{p}>0,05)$.

Przeanalizowano punktację doświadczeń badanych z opieki pielęgniarskiej w zależności od ilości nocy spędzonych przez respondentki w oddziale. Najlepsze doświadczenia związane $\mathrm{z}$ opieką pielęgniarską uzyskały pacjentki przebywające w oddziale powyżej 3 nocy - średnia 86,56 pkt. Osoby, które spędziły w oddziale do 3 nocy uzyskały średni wyniki 80,59 pkt. 


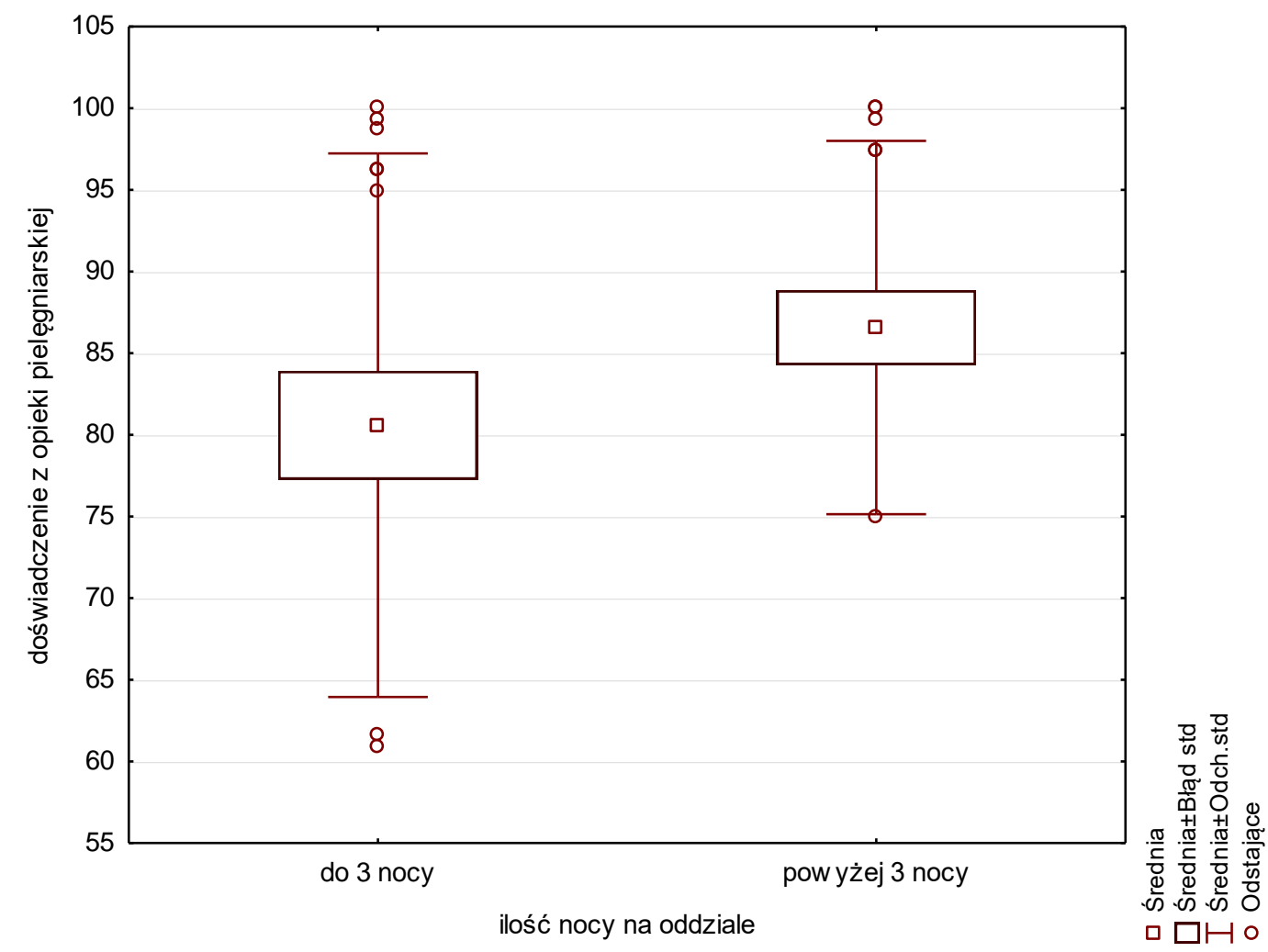

Rycina 3. Rozkład średnich punktacji doświadczeń badanych z opieki pielęgniarskiej w zależności od czasu trwania hospitalizacji.

Źródło: wynik badań własnych

Ze względu na poziom istotności p=0,229 ( $p>0,05)$, nie odnotowano istotnej statystycznie różnicy pomiędzy doświadczeniami badanych z opieki pielęgniarskiej, a czasem trwania hospitalizacji.

Przeanalizowano punktację dotyczącą doświadczeń badanych z opieki pielęgniarskiej w zależności od miejsca ich zamieszkania. Lepsze doświadczenia $\mathrm{w}$ tym zakresie uzyskały pacjentki 
zamieszkujące na wsi - średnia 83,88 pkt., w porównaniu do średniej mieszkanek miasta wynoszącej 82,86 pkt.

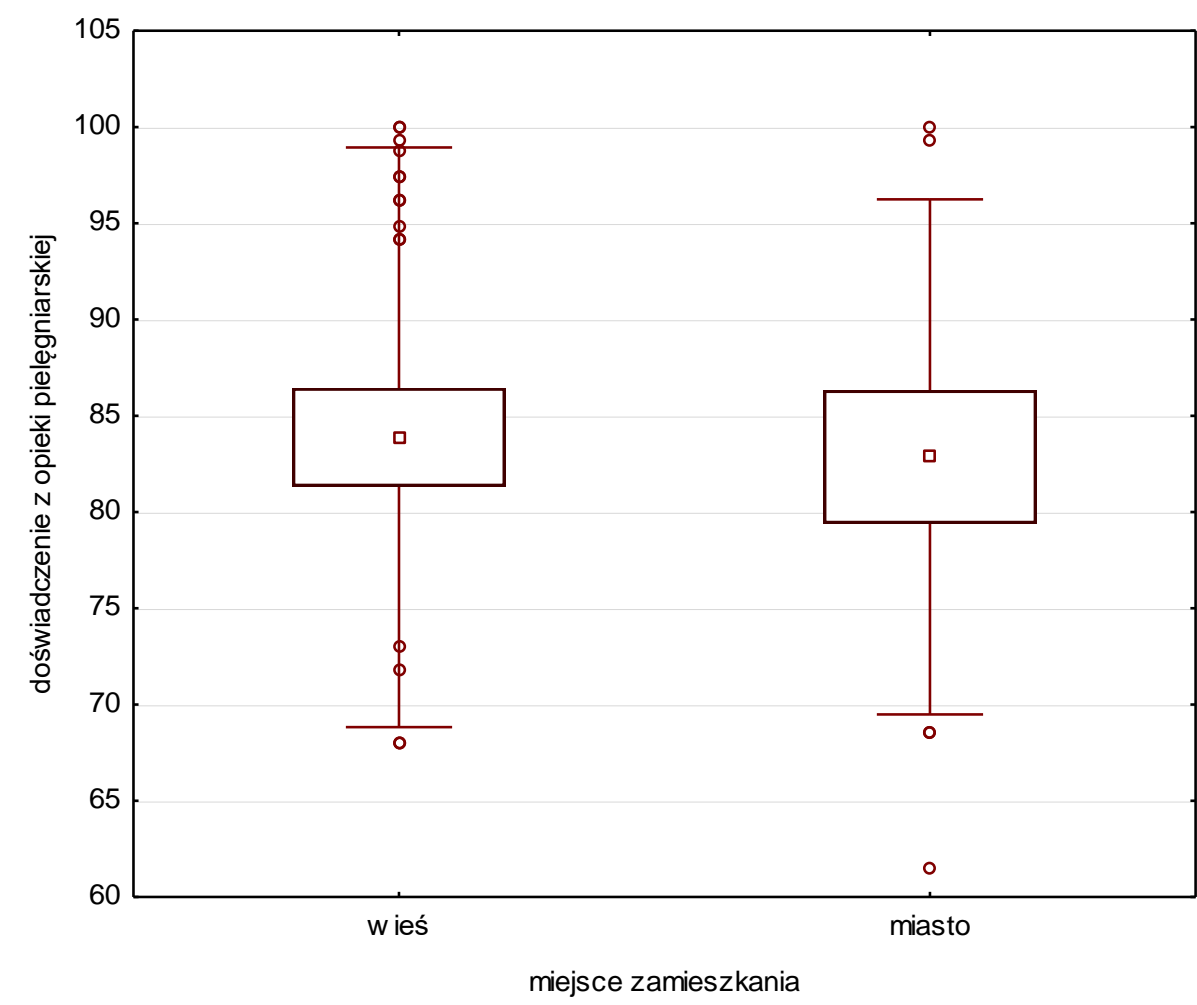

Rycina 4. Rozkład średnich punktacji doświadczeń badanych z opieki pielęgniarskiej w zależności od miejsca zamieszkania. Źródło: wynik badań własnych

Ze względu na poziom istotności p=0,539 (p>0,05) nie odnotowano istotnej statystycznie różnicy pomiędzy miejscem zamieszkania badanych a oceną ich doświadczeń z opieki.

Przeanalizowano punktację $\mathrm{w}$ zakresie doświadczenia badanych z opieki pielęgniarskiej w zależności od sprawowania opieki nad nimi przez wyznaczoną pielęgniarkę. Najwyższą liczbę punktów uzyskały respondentki, którymi opiekowała się konkretna 
pielęgniarka - średnia 84,74 pkt. Pacjentki, które nie miały wyznaczonej do opieki nad nimi pielęgniarki osiągnęły najniższy wynik mieszczący się na poziomie 83,01 pkt. Pacjentki, które nie były pewne, czy miały wyznaczoną do opieki nad nimi pielęgniarkę, osiągnęły najniższy wynik mieszczący się na poziomie 83,01 pkt.

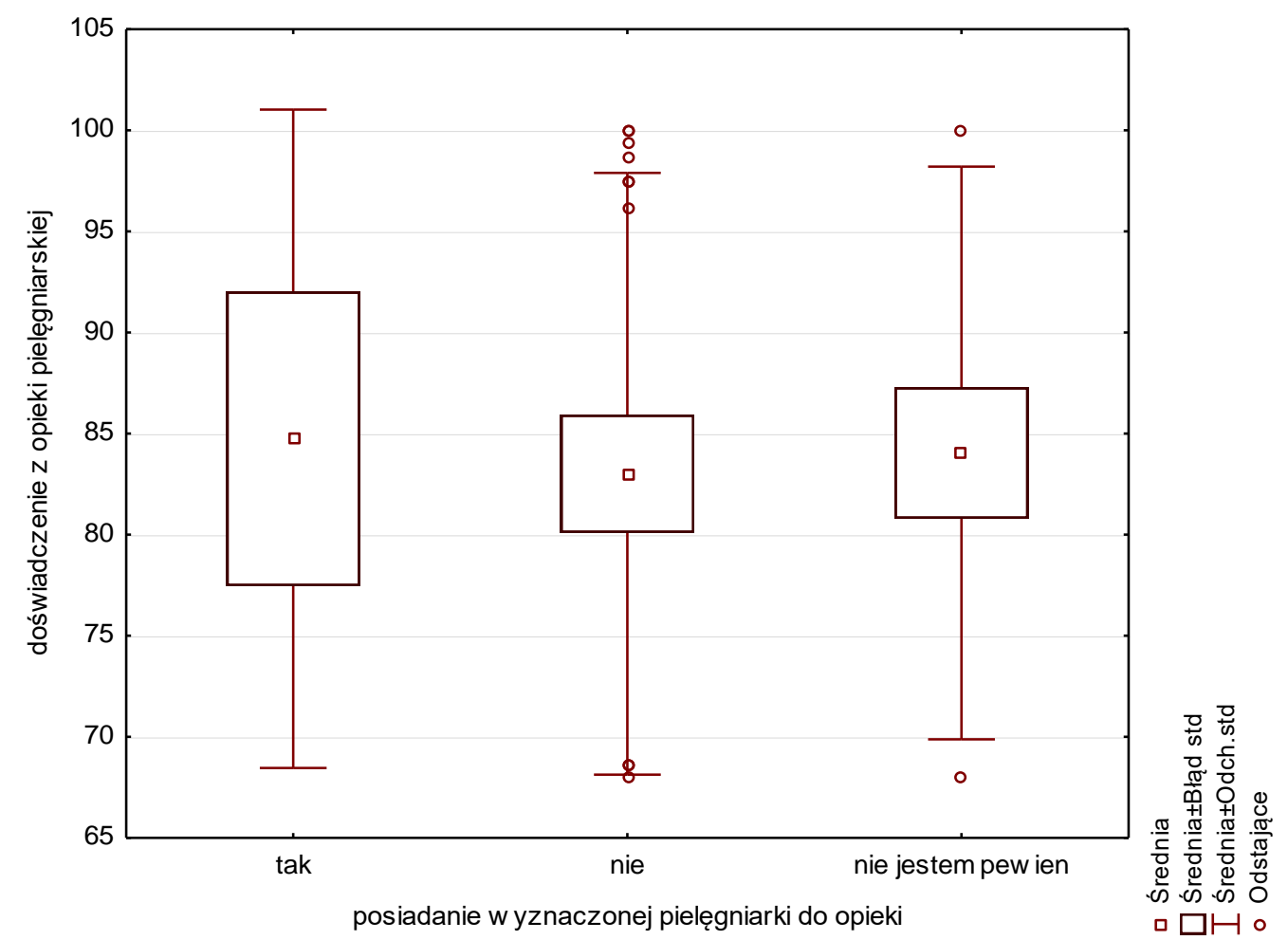

Rycina 5. Rozkład średnich punktacji doświadczeń badanych z opieki pielęgniarskiej w zależności od sprawowania opieki przez konkretną, wyznaczoną pielęgniarkę.

Źródło: wynik badań własnych

Wyznaczenie konkretnej pielęgniarski do sprawowania opieki nad pacjentem nie różnicowało istotnie oceny doświadczeń badanych $\mathrm{z}$ opieki pielęgniarskiej $\mathrm{p}=0,986(\mathrm{p}>0,05)$. 
Opieka sprawowana w oddziale szpitalnym nad noworodkiem może pośrednio wpłynąć na zakres opieki realizowanej przez rodziców/opiekunów w domu. Oddział noworodkowy jest zatem tym miejscem, w którym szczególną uwagę należy zwrócić na satysfakcję badanych z opieki pielęgniarskiej. Każda $\mathrm{z}$ pacjentek oddziału położniczego powinna zostać optymalnie przygotowana do opieki nad noworodkiem $\mathrm{w}$ domu. Badanie satysfakcji $\mathrm{z}$ opieki pielęgniarskiej w oddziale położniczo- noworodkowym jest zatem wyjątkowo ważne, ponieważ daje szanse na modyfikację działań i wdrożenie takich rozwiązań, które są najwyżej oceniane przez odbiorców świadczeń. Na poziom satysfakcji z opieki mają wpływ różne czynniki m.in. zakres wiedzy, jaki przekazywany jest przez personel opiekunom dziecka. Coraz więcej kobiet, informacji na temat pielęgnacji dziecka poszukuje nie tylko $\mathrm{w}$ internacie, ale i w różnych pozycjach na rynku wydawniczym. Jeśli informacje zamieszczone w wyżej wymienionych źródłach różnią się znacznie od tych, które przekazywane są przez personel może to wpłynąć na obniżenie poziomu zadowolenia z opieki. W przeprowadzonych aktualnie badaniach szczególną uwagę zwrócono na wpływ wybranych zmiennych socjodemograficznych, czas trwania hospitalizacji oraz korzystanie ze wsparcia ze strony pielęgniarek na postrzeganie jakości opieki sprawowanej przez personel medyczny.

Średnia ilość punktów możliwych do zdobycia przez ankietowanych $\mathrm{w}$ pytaniach dotyczących doświadczeń $\mathrm{z}$ opieki pielęgniarskiej przekraczała połowę możliwych do zdobycia, co wskazuje na wysoki poziom zadowolenia badanych ze sprawowanej przez personel opieki. Przeprowadzone badania nie wykazały jednak, istotnej zależności pomiędzy zmiennymi socjodemograficznymi, czasem trwania hospitalizacji oraz korzystaniem ze wsparcia ze strony pielęgniarek, a oceną doświadczeń $\mathrm{z}$ opieki pielęgniarskiej respondentek.

Badania Wierzbickiej oraz Jankowskiej-Polańskiej dotyczące poziomu jakości opieki pielęgniarskiej na przykładzie oddziałów 
Uniwersyteckiego Szpital Klinicznego we Wrocławiu z wykorzystaniem polskiej wersji skali zadowolenia z opieki Newcastle wykazały, że na ocenę doświadczeń badanych z opieki nie ma istotnego wpływu wiek respondentów. Poziom wykształcenia jednak w przeciwieństwie do wyników uzyskanych w aktualnych badaniach, zdaniem Wierzbickiej oraz Jankowskiej-Polańskiej wpływał istotnie na oceny doświadczeń z opieki dokonywanej przez respondentów [6]. W badaniach tych autorki wykazały również brak występowania istotności statystycznej pomiędzy doświadczeniami z opieki a czasem trwania hospitalizacji. Wynik ten zgodny jest $\mathrm{z}$ wynikiem aktualnych badań. Zauważyć trzeba jednak, ze wszelkie różnice w wynikach wynikać mogą z faktu, że badania te prowadzone były w kontekście osób dorosłych, w przeciwieństwie do aktualnych badań, które poza oceną opieki dotyczącą bezpośrednio matek, dotyczyły dodatkowo opinii nt. świadczeń realizowanych wobec ich dzieci.

W badaniach Kozimali i Putowskiego, w których analizowano poziom zadowolenia $\mathrm{z}$ opieki pielęgniarskiej $\mathrm{z}$ wykorzystaniem polskiej wersji skali Newcastle, zwrócono uwagę na zależność oceny doświadczeń z opieki i takich zmiennych socjodemograficznych jak: płeć, wiek oraz poziom wykształcenia. Autorzy nie stwierdzili jednak istotnej statystycznie zależności pomiędzy wykształceniem respondentów a poziomem oceny ich doświadczeń $\mathrm{z}$ opieki [7]. Podobnie jak $\mathrm{w}$ aktualnych badaniach przeprowadzonych $\mathrm{w}$ oddziale noworodkowym, Kozimala i Putowski nie zaobserwowali również istotnej statystycznie różnicy pomiędzy oceną doświadczeń z opieki w zależności od wieku ankietowanych. Brak tej zależności waktualnych badaniach tłumaczyć można jednak małą ilością respondentów. Aby określić czy wiek badanych wywiera istotny wpływ na ich poziom zadowolenia z opieki, należałoby przeprowadzić badania, którym zostanie poddana większa liczba osób. Grochans, Wieder-Huszla, Jurczak, Stanisławka, Janic oraz Szych w swoich badaniach dotyczących wsparcia emocjonalnego jako wyznacznika jakości opieki pielęgniarskiej prowadzonych w Oddziale Chirurgii 
Ogólnej Samodzielnego Publicznego Szpitala Rejonowego w Nowogardzie przedstawili stosunek wsparcia ze strony personelu do oceny jakości opieki sprawowanej przez personel [8]. Z badań tych wynika, że niektóre z czynników zwianych ze wsparciem ze strony personelu pielęgniarskiego takie jak: informowanie na temat pobytu $\mathrm{w}$ szpitalu, wyjaśnianie nomenklatury medycznej, informowanie o sposobie zachowania się po operacji, zapoznanie $\mathrm{z}$ topografią oddziału, zapewnienie troskliwej opieki, rozmowy, szybkie reagowanie na dzwonki mają istotny wpływ na poziom oceny jakości opieki. Wyniki te zgodne są z wynikam aktualnych badań.

\section{Wnioski}

1. Doświadczenia badanych dotyczące opieki pielęgniarskiej w okresie hospitalizacji nie różnią się istotnie w zależności od wybranych zmiennych socjodemograficznych (wiek, wykształcenie, miejsce zamieszkania), czasu hospitalizacji i korzystania ze wsparcia ze strony pielęgniarek.

2. Opieka sprawowana $\mathrm{w}$ oddziale szpitalnym nad matką i noworodkiem może pośrednio wpłynąć na zakres opieki realizowanej przez rodziców/opiekunów w domu. Oddział noworodkowy jest zatem tym miejscem, w którym szczególną uwagę należy zwrócić na satysfakcję badanych z opieki pielęgniarskiej.

\section{Zalecenia dla praktyki pielęgniarskiej}

Opieka sprawowana w oddziale szpitalnym nad matką i noworodkiem może pośrednio wpłynąć na zakres opieki realizowanej przez rodziców/opiekunów w domu. Oddział noworodkowy jest zatem tym miejscem, w którym szczególną uwagę należy zwrócić na satysfakcję badanych z opieki pielęgniarskiej. 


\section{Bibliografia / Bibliography:}

1. Mahon P.Y. An analysis of the concept of patients satisfaction as it relates to contemporary nursing care. Jurnal od Advanced Nursing,1996,24: 1241-48.

2. Johansson P., Oleni M., Fridlund B. Patrient satisfaction with nursing care In the co text of health care: a literature study. Nordic Collage of Caring Sciences. Scandinavian Journal of Caring SCIENCES,2002,(16):337-344.

3. Juszczak K., Jaracz K. Jakość opieki pielęgniarskiej w świetle aktualnych badań - przegląd piśmiennictwa. Polski Przegląd Nauk o Zdrowiu 2008,4:17.

4. Kowalik G.: Czynniki wpływające na jakość opieki pielęgniarskiej, Studia Medyczne Akademii Świętokrzyskiej, Kielce 2006, 4:337-344.

5. Rozporządzenie Ministra Zdrowia z dnia 16 sierpnia 2018 r. w sprawie standardu organizacyjnego opieki okołoporodowej. Poz. 1756.

6. Wierzbicka B.K., Jankowska-Polańska B. Poziom jakości opieki pielęgniarskiej na przykładzie oddziałów Uniwersyteckiego Szpitala Klinicznego we Wrocławiu. Współczesne Pielęgniarstwo i Ochrona Zdrowia 2014,3,4:90-96.

7. Kozimala M., Putowski L. Ocena satysfakcji pacjentów z opieki pielęgniarskiej w Centrum Opieki Medycznej w Jarosławiu. Annales Academiae Medicae Silesiensis 2009,63,1:20-27.

8. Grochans E., Wieder-Huszla S., Jurczak A., Stanisławka M., Janic E., Szych Z. Wsparcie emocjonalne jako wyznacznik jakości opieki pielęgniarskiej. Problemy Higieny i Epidemiologii 2009,90,2:236-239.

Otrzymano: 04.02.2019r.

Zaakceptowano: $15.03 .2019 \mathrm{r}$. 